\title{
ENGEVISTA
}

Página da revista: http://www.uff.br/engevista/seer/

\section{Measurement of fiber conversion levels in reducing sugars from hydrolyzed sugarcane bagasse with acid catalysts}

\author{
Lais Regina Gehlen ${ }^{1}$ \\ Eliane Hermes ${ }^{2}$ \\ Dilcemara Cristina Zenatti ${ }^{3}$ \\ Carlos Alexandre Alves Pessuti ${ }^{4}$ \\ Andre Luiz Canan ${ }^{5}$ \\ Jussara Silva Berger ${ }^{6}$
}

Resumo: O objetivo deste trabalho foi determinar a eficiência de redução de fibras em detergente neutro (FDN) e a conversão em açúcares redutores através de hidrólises ácidas. Foram utilizados dois tipos de ácidos fortes como catalisadores das reações: ácido sulfúrico $\left(\mathrm{H}_{2} \mathrm{SO}_{4}\right)$ nas concentrações de $0,05,0,1$ e $0,15 \mathrm{M}$ e ácido clorídrico (HCl) nas concentrações de $0,05 \%, 0,1 \%$ e 0,2\%. Foram aplicados diferentes tempos $(30,45$ e 60 minutos) e temperaturas $\left(80,100\right.$ e $\left.120{ }^{\circ} \mathrm{C}\right)$. Para $\mathrm{o}_{2} \mathrm{SO}_{4}$, a melhor hidrólise obtida foi no ensaio de número 4 com tempo de 60 minutos, temperatura de $120{ }^{\circ} \mathrm{C}$ e concentração de $\mathrm{H}_{2} \mathrm{SO}_{4}$ de 0,05 mol.L ${ }^{-1}$ com conversão em açúcares redutores de 93,54\%. Para o $\mathrm{HCl}$, o melhor resultado foi observado no ensaio de número 4 com tempo de 60 minutos, temperatura de $120^{\circ} \mathrm{C}$ e concentração de $\mathrm{HCl}$ de $0,05 \%$ com valor de $94,14 \%$. A hidrólise com $\mathrm{HCl}$ foi a que obteve os melhores resultados, alcançando os menores teores de fibras e maiores valores de eficiência de conversão em açúcares redutores. Os resultados obtidos foram de grande valia, sendo possível sua utilização em projetos futuros, visando à otimização das hidrólises para concluir o processo de digestão anaeróbia.

Palavras-chave: Digestão anaeróbia, hidrólise ácida, matéria-prima.

\footnotetext{
${ }^{1}$ UFPR - Universidade Federal do Paraná

2 UFPR - Universidade Federal do Paraná

${ }^{3}$ UFPR - Universidade Federal do Paraná

${ }^{4}$ UFPR - Universidade Federal do Paraná

${ }^{5}$ UFPR - Universidade Federal do Paraná

${ }^{6}$ UFRGS - Universidade Federal do Rio Grande do Sul
}

ENGEVISTA, V. 18, n. 2, p. 318-328, Dezembro 2016. 
ISSN: $1415-7314$

ISSN online: $2317-6717$

Abstract: This study aimed at determining the efficiency of neutral detergent fiber (NDF) reduction and conversion to reducing sugars by acid hydrolysis. Two kinds of strong acids as reaction catalysts were used: sulfuric acid $\left(\mathrm{H}_{2} \mathrm{SO}_{4}\right)$ at $0.05,0.1$ and $0.15 \mathrm{M}$ concentrations and hydrochloric acid $(\mathrm{HCl})$ at $0.05 \%, 0.1 \%$ and $0.2 \%$ concentrations. Different times (30, 45 and 60 minutes) and temperatures $\left(80,100,120{ }^{\circ} \mathrm{C}\right)$ were applied. For $\mathrm{H}_{2} \mathrm{SO}_{4}$, the best hydrolysis was obtained in essay 4 with 60 minutes, at $120{ }^{\circ} \mathrm{C}$ and $0.05 \mathrm{~mol} \mathrm{~L}^{-1} \mathrm{H}_{2} \mathrm{SO}_{4}$ concentration with $93.54 \%$ conversion to reducing sugars. While for $\mathrm{HCl}$, the best result was observed in essay 4 with 60 minutes, at $120{ }^{\circ} \mathrm{C}$ and $0.05 \% \mathrm{HCl}$ concentration of $94.14 \%$. Hydrolysis with $\mathrm{HCl}$ showed the best results, with the lowest levels of fiber and the highest conversion efficiency in reducing sugars. The results were quite important, since it will be possible to use them in future projects, aiming at optimizing the hydrolysis in order to complete the anaerobic digestion process.

Keywords: Anaerobic digestion, acid hydrolysis, raw material. 


\section{Introduction}

Biomass has been used as the main material for studies concerning alternative energy production. The sugarcane bagasse has potential energy to produce biogas through anaerobic digestion. It is a lignocellulosic waste, a by-product of the sugarcane industry and it can also be generated from its juice extraction (BNDES; CGEE, 2008).

Its residue consists mainly of cellulose, hemicellulose and lignin, which has about $28 \%$ sugarcane weight. Hemicellulose and cellulose are the most structural fractions of sugarcane bagasse and represent a potential source of sugars such as xylose and glucose. However, this sugar obtaining requires the application of techniques that allow their selective extraction (Betancur and Pereira Jr, 2010).

Currently, studies involving anaerobic bagasse digestion for biogas production, in order to improve this process, have been under development, although such technology has been established at lower operating costs. Initially, during hydrolysis phase, complex organic compounds are converted into simpler compounds (Morais and Broetto, 2012). This conversion process begins with the transformation of more complex particulate organic matter in dissolved materials, by specific hydrolytic exoenzymes excreted by fermentative bacteria (Teixeira et al., 2008).

Currently, the biomass treatment is accomplished by acid or enzymatic hydrolysis, which are technologies under improvement, although acid hydrolysis is the most prominent (Morais and Broetto, 2012). This consists of adding more diluted or concentrated acids and aims at solubilizing hemicellulose as well as making cellulose more accessible to digestion (Hamenlick et al., 2005). This hydrolysis requires a shorter time of reaction as well as lower spending on chemicals and energy when compared to enzymatic hydrolysis (Ogeda and Petri, 2010).

During the hydrolysis occur the fibers conversion in reducing sugars. Carbohydrates are the most abundant macronutrients and are classified into mono, oligo and polysaccharides. Monosaccharides are non-hydrolysable simple sugars, i.e, reducing sugars (Silva et al., 2003), however, in order to obtain these sugars, it is required the application of techniques to extract them, in this case, by acid hydrolysis. Combinations of acid concentration, temperature and reaction time can generate large amounts of sugar from this fraction. After the conversion of fibers in reducing sugars, these ones are recovered for subsequent fermentation to keep on the biogas production process.

Thus, the present study aimed at analyzing the effectiveness of acid hydrolysis with sulfuric and hydrochloric acid under different concentrations of sugarcane bagasse.

\section{Material and methods}

The material was collected in a place where we can get sugarcane juice and took to the laboratory to grind its residue into pieces of approximately $3 \mathrm{~cm}$ diameter and easy its 
characterization. For the initial characterization, the evaluated parameters were neutral detergent fiber (NDF) and reducing sugar.

For hydrolysis, sulfuric acid $\left(\mathrm{H}_{2} \mathrm{SO}_{4}\right)$ and hydrochloric acid $(\mathrm{HCl})$ were the strong catalyst acids used. The applied concentrations were $0.05 \mathrm{M}, 0.1 \mathrm{M}$ and $0.15 \mathrm{M}$ for $\mathrm{H}_{2} \mathrm{SO}_{4}$ and $0.05 \%, 0.1 \%$ and $0.2 \%$ for $\mathrm{HCl}$.

The trials of acid hydrolysis followed a factorial experimental design, with these independent variables: temperature, hydrolysis time and acid concentration. The following $2^{\mathrm{n}}=2^{3}=8$ treatments were performed in which ' $n$ ' is the number of variables, where each one is at two coded levels as +1 and -1; a central treatment was repeated 4 times. All factors are at a medium level, coded as zero, totaling 12 experiments (Table 1).

Table 1. Experimental design at $-1,0$ e +1 .

\begin{tabular}{l|l|ccc}
\hline & \multicolumn{1}{c}{ Levels } & $\mathbf{- 1}$ & $\mathbf{0}$ & $\mathbf{+ 1}$ \\
& Variables & & & \\
\hline \multirow{3}{*}{ Hydrolysis } & Temperature $\left({ }^{\circ} \mathrm{C}\right)$ & 80 & 100 & 120 \\
$\mathrm{H}_{2} \mathrm{SO}_{4}$ & Time $(\mathrm{min})$ & 30 & 45 & 60 \\
& {[]$_{2} \mathrm{SO}_{4}$} & $0.05 \mathrm{M}$ & $0.1 \mathrm{M}$ & $0.15 \mathrm{M}$ \\
\hline & \multicolumn{1}{c}{ Levels } & $\mathbf{- 1}$ & $\mathbf{0}$ & $\mathbf{+ 1}$ \\
& Variables & & & \\
\hline \multirow{3}{*}{$\mathrm{Hydrolysis}$} & Temperature $\left({ }^{\circ} \mathrm{C}\right)$ & 30 & 100 & 120 \\
$\mathrm{HCl}$ & Time $(\min )$ & 30 & 45 & 60 \\
\hline & {$[$ ] $\mathrm{HCl}$} & $0.05 \%$ & $0.1 \%$ & $0.2 \%$ \\
\hline
\end{tabular}

The hydrolytic trials started with $10 \mathrm{~g}$ samples, which corresponded to $0.435 \mathrm{~g}$ dry matter. The samples were packed in $100 \mathrm{ml}$ polyethylene bottles and added $50 \mathrm{ml}$ of acid solution for hydrolyses. Afterwards, they were placed in an oven or autoclave depending on the temperature required. The trials were carried out in a greenhouse at $80{ }^{\circ} \mathrm{C}$ and $100{ }^{\circ} \mathrm{C}$ temperatures with both air exchange and circulation. On the other hand, the trials at $120^{\circ} \mathrm{C}$ were carried out at 1 atmosphere (atm) pressure in autoclave.

After each trial, the hydrolysate was filtered and collected in a $50 \mathrm{ml}$ beaker. Then, it was stored in a test tube and kept at $-18^{\circ} \mathrm{C}$ until the reducing sugars analyses. The solid residue was taken to the greenhouse at $65{ }^{\circ} \mathrm{C}$ for drying and subsequent fiber analysis. During the fiber analyses, the NDF - Neutral Detergent Fiber - reagent was prepared according to the Brazilian Compendium of Animal Nutrition Protocol. For the reducing sugars analyses, SN-1 and SN-2 solutions were prepared according to the Embrapa protocol, Somogy and Nelson method (Maldonade et al., 2013)

After all the studied procedures, the hydrolysis efficiency was evaluated according to the fiber reduction (NDF) and the increasing concentration of reducing sugars. In order to determine the best treatment and the influence of applied variables, a statistical analysis at 5\% probability was carried out with the STATISTICA $®$ software, version 7.0 (STATSOFT TM, USA). 


\section{Results and discussion}

During the initial characterization, \% NDF values and reducing sugar concentration were $84.81 \%$ and $936.91 \mathrm{mg} \mathrm{L}^{-1}$, respectively. Carvalho et al. (2009) researched about the characterization of sugarcane bagasse, thus, NDF content was $63 \%$, therefore, it was lower than the answer already obtained in this trial. While Mota et al. (2010) recorded that its studied bagasse showed $45.25 \%$ for initial NDF content parameter. Consequently, the following procedures conditions have influenced on temperature, time and moisture of bagasse. The values of NDF (\%) and conversion efficiency on reducing sugars (\%), quantified in both hydrolyses, are shown on Table 2.

Table 2. Values for NDF (\%) and conversion efficiency in reducing sugars for hydrolyses with $\mathrm{H}_{2} \mathrm{SO}_{4}$ and $\mathrm{HCl}$.

\begin{tabular}{ccccccccc}
\hline Essay & $\mathrm{t}(\mathrm{min})$ & $\begin{array}{c}\mathrm{T} \\
\left({ }^{\circ} \mathrm{C}\right)\end{array}$ & $\begin{array}{c}{\left[\mathrm{H}_{2} \mathrm{SO}_{4}\right]} \\
\left(\mathrm{mol} \mathrm{L}^{-1}\right)\end{array}$ & $\begin{array}{c}\mathrm{NDF} \\
(\%)\end{array}$ & $\begin{array}{c}\text { Reducing } \\
\text { Sugars } \\
\text { Conversion } \\
(\%)\end{array}$ & $\begin{array}{c}{[\mathrm{HCl}]} \\
\left(\mathrm{mol} \mathrm{L}^{-1}\right)\end{array}$ & $\begin{array}{c}\text { NDF } \\
(\%)\end{array}$ & $\begin{array}{c}\text { Reducing } \\
\text { Sugars } \\
\text { Conversion } \\
(\%)\end{array}$ \\
\hline 1 & 30 & 80 & 0.05 & 84.85 & 91.91 & 0.05 & 79.84 & 89.74 \\
2 & 30 & 120 & 0.05 & 76.09 & 92.43 & 0.05 & 72.35 & 92.84 \\
3 & 60 & 80 & 0.05 & 87.87 & 75.89 & 0.05 & 75.75 & 90.59 \\
4 & 60 & 120 & 0.05 & 76.35 & 93.54 & 0.05 & 81.00 & 94.14 \\
5 & 30 & 80 & 0.15 & 86.68 & 80.30 & 0.20 & 86.79 & 93.03 \\
6 & 30 & 120 & 0.15 & 78.26 & 92.24 & 0.20 & 70.74 & 92.77 \\
7 & 60 & 80 & 0.15 & 85.61 & 91.89 & 0.20 & 72.81 & 92.03 \\
8 & 60 & 120 & 0.15 & 81.68 & 91.95 & 0.20 & 70.80 & 92.56 \\
9 & 45 & 100 & 0.10 & 87.45 & 92.03 & 0.10 & 82.71 & 91.44 \\
10 & 45 & 100 & 0.10 & 89.47 & 91.79 & 0.10 & 83.89 & 92.65 \\
11 & 45 & 100 & 0.10 & 81.17 & 91.51 & 0.10 & 79.37 & 92.80 \\
12 & 45 & 100 & 0.10 & 85.07 & 91.74 & 0.10 & 82.98 & 91.98 \\
\hline
\end{tabular}

Hydrolysis with $\mathrm{H}_{2} \mathrm{SO}_{4}$ showed high levels of fiber even after the hydrolytic process, an average NDF value of $83.38 \%$ and $\pm 4.59 \%$ standard deviation. The best result, with the lowest percentage of fiber, was observed in the essay number 2 , at which a 30 -minute time, $120^{\circ} \mathrm{C}$ and 0.05 mol. $\mathrm{L}^{-1} \mathrm{H}_{2} \mathrm{SO}_{4}$ concentration were used. Essay number 10 showed that the highest NDF content after hydrolysis, one of the central point replicas, at which 45 -minute time, $100{ }^{\circ} \mathrm{C}, 0.10 \mathrm{~mol} \cdot \mathrm{L}^{-1}$ acid concentration were used, and whose NDF value was $89.47 \%$.

In this same hydrolysis, there were high conversion values of reducing sugars, with an average $89.77 \%$ answer and a standard deviation of $\pm 5.56 \%$. The best result was observed in essay number 4 , at which 60 -minute time, $120{ }^{\circ} \mathrm{C}$ and 0.05 mol. $\mathrm{L}^{-1}$ sulfuric acid concentration were used. Essay number 3 showed the lowest conversion of reducing sugars after hydrolysis, with the same time and the same acid concentration, however, with lower temperature $\left(80^{\circ} \mathrm{C}\right)$, whose obtained value for conversion sugars was $75.89 \%$. 
Aguilar et al. (2002) in sugar cane bagasse hydrolysis with $\mathrm{H}_{2} \mathrm{SO}_{4}$ at concentrations of 2, 4 and $6 \%$ determined as optimum conditions the concentration of $2 \% \mathrm{H}_{2} \mathrm{SO}_{4}$ at a temperature of 122 ${ }^{\circ} \mathrm{C}$ and time of 24 minutes, taking approximately $90 \%$ hemicellulose hydrolyzate.

Morais and Broetto (2012) evaluated the acid pre-hydrolysis of sugarcane bagasse in hydrolysis times of 15, 30, 45 and 60 minutes. The authors used 7.0 and $9.0 \% \mathrm{H}_{2} \mathrm{SO}_{4}$ concentration and found out that the best treatment for the release of reducing sugars occurred at 30 and 45 minutes, with 7.0 and $9.0 \% \mathrm{H}_{2} \mathrm{SO}_{4}$ concentrations. So, 6.89 and $6.60 \mathrm{gL}^{-1}$ reducing sugars were released, respectively. These data showed an increase of 22.4 and 17.1 times in relation to the reducing sugars concentration.

According to Gurgel et al. (2012) the maximum glucose yields reached $67.6 \%\left(200{ }^{\circ} \mathrm{C}\right.$, $\left.0.07 \% \mathrm{H}_{2} \mathrm{SO}_{4}, 30 \mathrm{~min}\right), 69.8 \%\left(210{ }^{\circ} \mathrm{C}, 0.14 \% \mathrm{H}_{2} \mathrm{SO}_{4}, 10 \mathrm{~min}\right)$ and $67.3 \%\left(210{ }^{\circ} \mathrm{C}, 0.28 \% \mathrm{H}_{2} \mathrm{SO}_{4}, 6\right.$ $\min$ ) in acid hydrolysis of sugar cane bagasse.

Acid hydrolysis with $\mathrm{HCl}$ showed acceptable values of fibers even after the hydrolytic process, with $78.25 \%$ NDF average value and $\pm 5.33 \%$ standard deviation. The best results, the lowest percentage of fibers, was observed in essay number 6, at which 30 -minute time, $120{ }^{\circ} \mathrm{C}$ and $0.20 \%$ hydrochloric acid concentration were used and obtained 70.74\% NDF. The essay number 5 showed that the highest NDF content after hydrolysis, at which 30 -minute time, $80{ }^{\circ} \mathrm{C}$ and $0.20 \%$ acid concentration were used and $86.79 \%$ NDF value was obtained.

On the other hand, hydrolysis with $\mathrm{HCl}$ showed $92.21 \%$ average for converting reducing sugars, considered as high values, and $\pm 1.12 \%$ standard deviation. The best result was observed in essay number 4 , at which 60 -minute time, $120{ }^{\circ} \mathrm{C}$ and $0.05 \%$ hydrochloric acid concentration were used. While, essay number 1 showed the lowest reducing sugar conversion after hydrolysis, at which 30-minute time, $80^{\circ} \mathrm{C}$ and $0.05 \%$ acid concentration were used, and the obtained value for sugar conversion was $89.74 \%$.

Aguilar et al. (2002) describe the acids commonly used in the process of hydrolysis release protons that act on glycosidic bonds that occur between sugar monomers in polymer chains. With the breaking of these bonds several compounds are released, especially sugars like glucose and xylose.

In Pareto diagram (Figure 1), it can be seen the variables influence on hydrolysis process of sugarcane bagasse for the NDF dependent variable. 


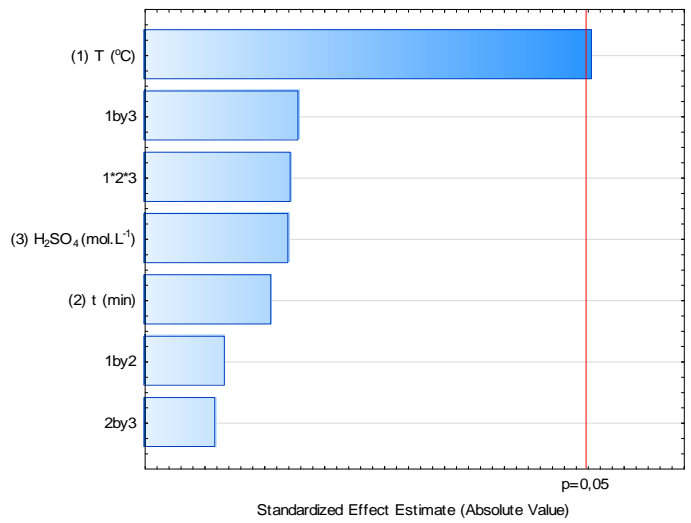

(a)

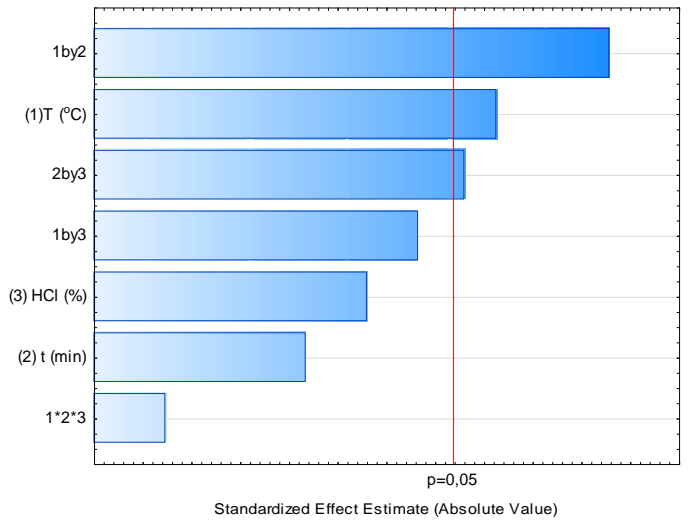

(b)

Figure 1. Pareto diagram for NDF variable in hydrolysis with $\mathrm{H}_{2} \mathrm{SO}_{4}$ (a) and $\mathrm{HCl}$ (b)

According to Figure 1a, it is observed that only the temperature has a significant effect during the hydrolysis process, with no other significant variables. On Figure 1b, the most important variable is the combination between temperature and time for the hydrolysis process, followed by temperature and the combination between time and concentration. Despite the reactions complexity, the pondering factor during the hydrolysis process is not the kinetics reaction, but the difficulty in reaching the reaction region of cellulose molecule by catalysts. The strong bond among cellulose, hemicellulose and lignin is characterized as one of the factors that controlled this access (Rao et al., 2006).

The behavior of the hydrolysis process in NDF reducing with $\mathrm{H}_{2} \mathrm{SO}_{4}$ and $\mathrm{HCl}$ are shown in Figure 2. As can only display the response surface only two independent variables, chose the variables that showed greater significant effect.

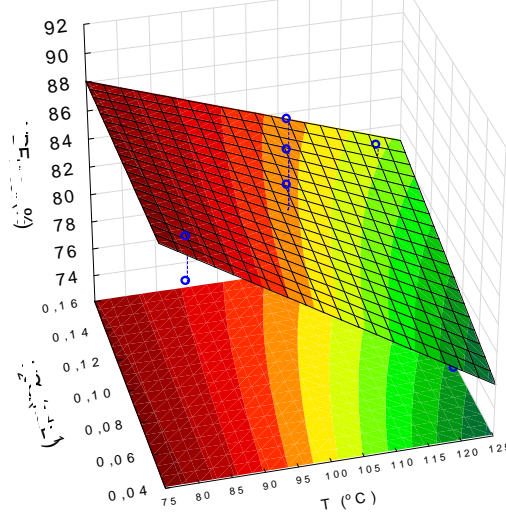

(a)

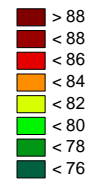

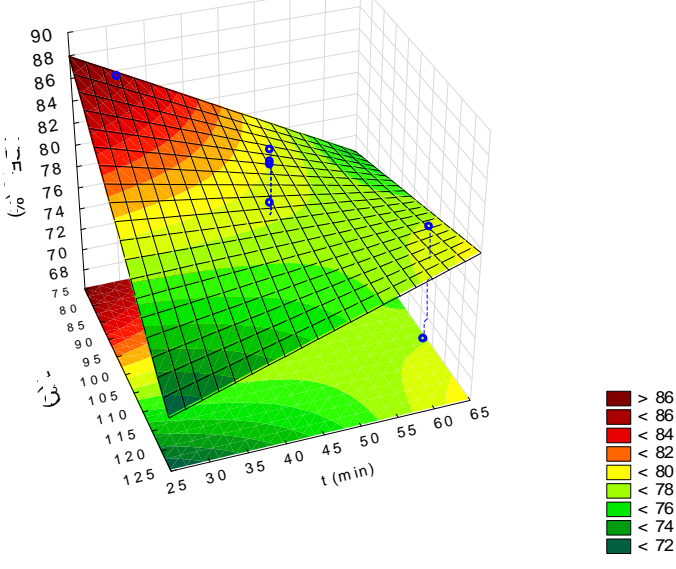

(b)

Figure 2 Response surface NDF conversion efficiency with $\mathrm{H}_{2} \mathrm{SO}_{4}$ (a) and $\mathrm{HCl}$ (b) 
The rise in temperature has a negative effect on the variable NDF conversion, wherein the concentration of of $\mathrm{H}_{2} \mathrm{SO}_{4}$ (Figure 2a) does not influence this variable. For the conversion of NDF with $\mathrm{HCl}$ (Figure 2b) it is observed that maintaining the concentration at the midpoint the shorter times and lower temperatures have better conversion efficiency.

In Pareto diagram (Figure 3), it can be observed the influence of variables in the hydrolysis process of sugarcane bagasse for the dependent variable conversion of sugars.

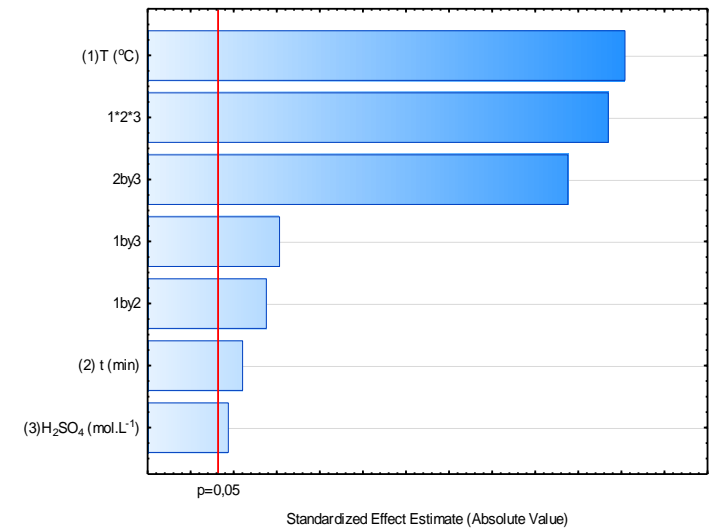

(a)

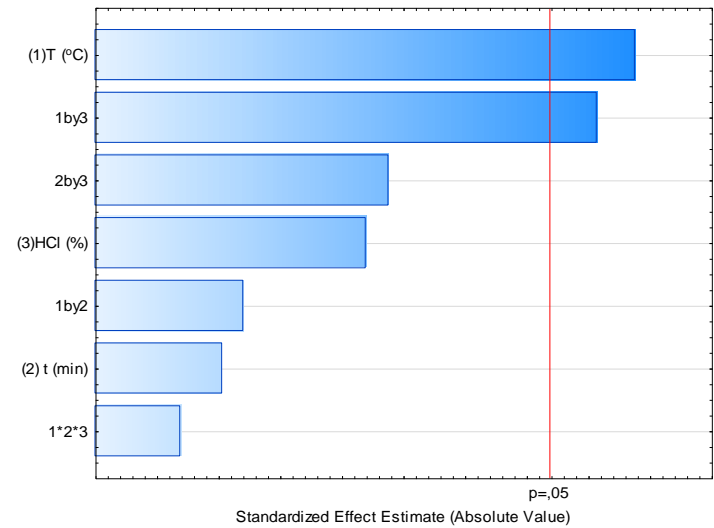

(b)

Figure 3. Pareto diagram for the variable sugars conversion in hydrolysis with $\mathrm{H}_{2} \mathrm{SO}_{4}$ (a) and $\mathrm{HCl}$ (b)

$\mathrm{To}_{2} \mathrm{SO}_{4}$ (Figure 3a) all variables influence significantly the process at the 95\% significance level, and temperature, the interaction between the three independent variables (temperature, time and acid concentration) and the interaction time and acid concentration had greater effect. For sugars conversion with $\mathrm{HCl}$ (Figure 3b) the variable temperature and the interaction acid concentration and temperature were the ones that influenced the process.

Morais and Broetto (2012) found out that during the pre-treatment of sugarcane bagasse hydrolysis for 60 minutes, the determined concentrations of reducing sugars did not increase when compared with the values obtained in the hydrolysis for 45 minutes. Thus, the 15-minute increase in autoclaving did not increase the obtained sugar production. A shorter time for the heat treatment indicates some cost reduction during the process.

The behavior of the hydrolysis process for sugars conversion with $\mathrm{H}_{2} \mathrm{SO}_{4}$ and $\mathrm{HCl}$ are shown in Figure 4. For shorter times and lower acid concentrations and longer times combined with higher concentrations of $\mathrm{H}_{2} \mathrm{SO}_{4}$ (Figure 4a), were obtained the best results. With the use of $\mathrm{HCl}$ (Figure $4 \mathrm{~b}$ ) the highest values of temperature and acid concentration promoted a higher sugars conversion. 
ISSN: 1415-7314

ISSN online: 2317-6717

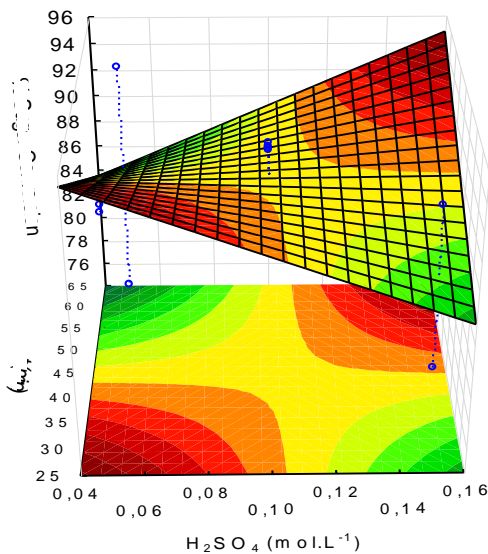

(a)

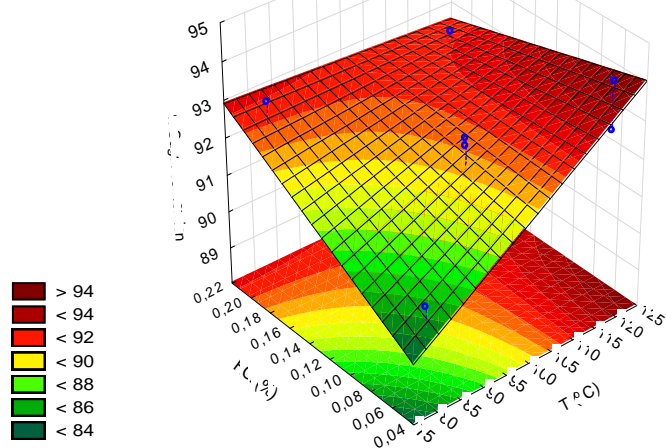

(b)

Figure 4. Response surface of sugars conversion efficiency with $\mathrm{H}_{2} \mathrm{SO}_{4}$ (a) and $\mathrm{HCl}$ (b)

In Table 3 are presented the equations, the coefficients of determination $\left(\mathrm{R}^{2}\right)$ and the values of $\mathrm{F}$ ratio $(\mathrm{Fcal} / \mathrm{Ftab})$ for NDF reduction $(\%)$ and reducing sugars conversion $(\%)$, in combinations $\mathrm{H}_{2} \mathrm{SO}_{4}$ and $\mathrm{HCl}$ with time and temperature. To obtaining the equations 1 to 4 took into account only the factors that influenced significantly, ie, those with $\mathrm{p}$-value $<0,05$.

Table 3. Regression models obtained for NDF reduction (\%) and reducing sugars conversion (\%), in combinations $\mathrm{H}_{2} \mathrm{SO}_{4}$ e $\mathrm{HCl}$ with time and temperature.

\begin{tabular}{lcc}
\hline \multicolumn{1}{c}{$\mathrm{H}_{2} \mathrm{SO}_{4}$} & & \\
Regression Model & $\mathrm{R}^{2}$ & $\mathrm{~F}_{\mathrm{ca}} / \mathrm{F}_{\mathrm{tab}}$ \\
\hline $\begin{array}{l}\text { (Eq. 1) FDN reduction }(\%)=83,38-8,16 \mathrm{~T} \\
\text { (Eq. 2) Sugars conversion }(\%)=89,77+7,54 \mathrm{~T}-0,90 \mathrm{t}+0,65\left[\mathrm{H}_{2} \mathrm{SO}_{4}\right]+1,31\end{array}$ & 0,58 & 2,11 \\
T.t $-1,54 \mathrm{~T} .\left[\mathrm{H}_{2} \mathrm{SO}_{4}\right]-6,55 \mathrm{t} .\left[\mathrm{H}_{2} \mathrm{SO}_{4}\right]-7,25 \mathrm{~T} . \mathrm{t} .\left[\mathrm{H}_{2} \mathrm{SO}_{4}\right]$ & 1155,10 \\
\hline \multicolumn{1}{c}{$\mathrm{HCl}$} & & \\
Regression Model & $\mathrm{R}^{2}$ & $\mathrm{~F}_{\mathrm{ca}} / \mathrm{F}_{\mathrm{tab}}$ \\
\hline (Eq. 3) FDN reduction $(\%)=78,25-5,08 \mathrm{~T}+6,70 \mathrm{~T} . \mathrm{t}-4,62 \mathrm{t} .[\mathrm{HCl}]$ & 0,54 & 11,56 \\
(Eq. 4) Sugars conversion $(\%)=92,21+1,73 \mathrm{~T}-1,59 \mathrm{~T} .[\mathrm{HCl}]$ & 0,73 & 6,53 \\
\hline
\end{tabular}

The coefficient of determination $\mathrm{R}^{2}$ quantifies the adjustment quality, because it provides a measure of variance proportion, explained by the regression equation in relation to the total variation of responses. Thus it can be seen that the models found to NDF not exhibit satisfactory adjustment, being 58 and $54 \%$ for hydrolysis with $\mathrm{H}_{2} \mathrm{SO}_{4}$ and $\mathrm{HCl}$, respectively. As for variable sugars conversion the model provides a good fit for both hydrolysis, this variable being explained in $93 \%$ when used $\mathrm{H}_{2} \mathrm{SO}_{4}$ as a catalyst and $73 \%$ when the catalyst is $\mathrm{HCl}$.

The $\mathrm{F}$ test shows the ratio between the $\mathrm{F}$ calculated and $\mathrm{F}$ tabulated and, when this ratio exceeds 1 , the regression is considered statistically significant, with the relationship between the independent and dependent variables. However, that model is useful for predicting, the value of this ratio should exceed 4 (Barros Neto, 2007). In the cases represented by the equations 1 to 4 all models 
can be considered statistically significant and only the model for NDF using $\mathrm{H}_{2} \mathrm{SO}_{4}$ as catalyst (equation 1) cannot be considered predictive, because presents relation Fcal/Ftab equal to $2.11<4$.

\section{Conclusion}

Concerning the initial characterization of sugarcane bagasse, the obtained values for NDF and reducing sugar were $84.81 \%$ and $936.91 \mathrm{mg} \mathrm{L}^{-1}$, respectively.

The hydrolysis with $\mathrm{HCl}$ showed the best results with the lowest levels of fiber and higher conversion efficiency in reducing sugars.

According to the obtained results, both improvement and optimization of hydrolysis for biogas production are aimed for future researches, since this is a promising area regarding better utilization of sugarcane bagasse.

\section{REFERENCES}

AGUILAR, R., RAMÍREZ, J. A., GARROTE, G., VÁSQUEZ, M. 2002. Kinetic study of the acid hydrolysis of sugar cana bagasse. Journal of Food Engineering, 55, 309-318.

BARROS NETO, B. 2007. Como fazer experimentos: pesquisa e desenvolvimento na ciência e na indústria. 3 ed. Campinas, 480p.

BETANCUR, G. J. V., PEREIRA JR. N. 2010. Sugarcane bagasse as feedstock for second generation ethanol production. Part I: diluted acid pre-treatment optimization. Electronic Journal of Biotechnology, 13, 1-9

BNDES; CGEE. 2008. Bioethanol from sugarcane: energy for sustainable development. Rio de Janeiro, 316p.

CARVALHO, G. G. P., CAVALI, J., FERNANDES, F. E. P., ROSA, L. O., OLIVINDO, C. S., PORTO, M. O., PIRES, A. J. V., GARCIA, R. 2009. Chemical composition and dry matter digestibility of sugarcane bagasse treated with calcium oxide. Brazilian Journal of Veterinary Medicine and Animal Science, 61, 1346-1352.

GURGEL, L. V. A., MARABEZI, K., ZANBOM, M. D., CURVELO, A. A. S. 2012. Dilute acid hydrolysis of sugar cane bagasse at high temperatures: A kinetic study of cellulose saccharification and glucose decomposition. Part I: sulfuric acid as the catalyst. Industrial \& Engineering Chemistry Research, 51, 1173-1185.

HAMENLICK, C., VAN HOOIJDONK, G., FAAIJ, A. 2005. Ethanol form lignocellulosic biomass: techno-economic performance in short, middle and long-term. Biomass and Bioenergy, 28, 384-410. MALDONADE, I. R., CARVALHO, P. G. B., FERREIRA, N. A., MOULIN, B. S. F. 2013. Protocol for determination of reducing sugars by the Somogy-Nelson method. EMBRAPA, 86, 1-4.

MORAIS, A. P. S., BROETTO, F. 2012. Acid pre-hydrolysis of sugarcane bagasse and it physicochemical characterization. Agricultural Energy Journal, 27, 1-12.

MOTA, D. A., OLIVEIRA, M. D. S., DOMINGUES, MANZI, G. M., FERREIRA, D. S., SANTOS, J. 2010. Hydrolysis of sugarcane with quicklime or hydrated lime. Brazilian Journal of Animal Science, 39, 1186-1190.

OGEDA, T. L., PETRI, D. F. S. 2010. Biomass Enzymatic Hydrolysis. Química Nova, 33, 15491558.

RAO, R. S., JYOTHI, P. C., PRAKASHAM, R. S., SARMA, P. N., RAO. L. V. 2006. Xylitol Production from corn fiber and sugarcane bagasse hydrolysates by Candida tropicalis. Bioresource Technology, 97, 1974-1978. 
SILVA, R. N., MONTEIRO, V. N., ALCANFOR, J. D. X., ASSIS, E. M., ASQUIERI, E. R. 2003. Comparision methods for the determination of reducers sugars an total in honey. Food Science and Technology, 23, 337-341.

TEIXEIRA, A. R., CHERNICHARO, C. A. L., AQUINO, S. F. 2008. Influence of particle size reduction on the hydrolisis rate of domestic raw sewage. Engenharia Sanitária e Ambiental, 13, 405415. 